\title{
Lectotypifications in Brachystelma (Apocynaceae: Ceropegieae)
}

\author{
Kambale, S.S. ${ }^{*}$ and M.K. Janarthanam ${ }^{2}$ \\ 'Department of Botany, Maratha Vidya Prasarak Samaj's Arts, Commerce \& Science College, \\ Tryambakeshwar, Maharashtra - 422 212, India. \\ 2Department of Botany, Goa University, Goa- 403 206, India. \\ E-mail: skambalesu@gmail.com
}

\begin{abstract}
The names Brachystelma bourneae Gamble, B. glabrum Hook.f. and B. maculatum Hook.f. are lectotypified. Lectotypes (second step) are designated for $B$. laevigatum Wight and $B$. volubile Hook.f. Notes on typification are provided and the inappropriate ending of $B$. edulis is corrected according to Art. 60.8 of ICN.
\end{abstract}

Keywords: Brachystelma, Burma, India, lectotypification

\section{Introduction}

The genus Brachystelma R.Br. (Apocynaceae), represented by more than 160 species (The Plant List, 2013; Prasad et al., 2018), is distributed in Africa, India, Sri Lanka, Myanmar, Malaysia, Thailand, Philippines, Papua New Guinea and Northern Australia (Meve, 2002). After the recent discoveries of new species by Kambale et al. (2014), Britto and Bruyns (2016), Sardesai et al. (2017) and Prasad et al. $(2017,2018)$ the genus is now represented by 30 species in India. As part of a taxonomic revision of Brachystelma in India, it is found that three names: Brachystelma bourneae Gamble, $B$. glabrum Hook.f. and B. maculatum Hook.f. need to be typified and two names B. laevigatum (Wight) Hook.f (EEriopetalum laevigatum Wight) and $B$. volubile Hook.f. need second step lectotypification to narrow down the type to single specimen. After perusal of relevant literature, protologues and consulting the type specimens at CAL, $\mathrm{MH}$ and $\mathrm{K}$ the most representative specimens have been designated as lectotypes, following article 9.3 of the Shenzhen Code (Turland et al., 2018).

Brachystelma bourneae Gamble, Bull. Misc. Inform. Kew 1922 (3): 120. 1922.

Lectotype (designated here): INDIA, Tamil Nadu, Perumal \& Vilpatty valley, 16.6.1899, Sir A.G. \& Lady Bourne 2751 (K000820012, digital image!).

Notes: Gamble (1922) described B. bourneae based on the collections from Pulney hills, Perumal and Vilpatty by Sir A.G. and Lady Bourne. Gamble cited three specimens (1020, 2751 and 2752) in the protologue. These specimens are wrongly placed under B. maculatum in the catalogue of Kew herbarium (http://www.kew.org/herbcat). Jagtap and Singh (1999) also cited these three specimens as type and indicated that they are in $\mathrm{K}$. We have chosen one complete specimen, Bourne 2751 (K000820012) which agrees well with the protologue, as the lectotype.

Brachystelma edule Collet \& Hemsl., J. Linn. Soc., Bot. 28. 89 t. 14. 1890.

Lectotype (Jagtap \& Singh 1999: 181): Plate by Coll. \& Helmsl. in J. Linn. Soc., Bot. 28: 89, t. 14. 1890.

Notes: Collett and Hemsley (1890) described B. edule (as B. edulis) based on the collections from Pyawbwe, Upper Burma. Jagtap and Singh (1999) cited the protologue figure as the type for the name. But, later Meve (2002) cited "Type: Myanmar, Collett \& Hemsley s.n. K!" as type to give a specimen priority over an illustration. However, in this case, the earlier lectotypification cannot be superseded and the protologue figure remains as lectotype. In many literatures including Jagtap and Singh (l.c.) the epithet has been cited as 'edulis' as it was the epithet used in the protologue. However, as the generic name Brachystelma is a Greek neuter noun, the epithet also should follow the gender of the genus and should be spelled as 'edule' (neuter) rather than 'edulis' (feminine). Epithets with inappropriate terminations are correctable error according to Art. 60.8 of ICN (Turland et al., 2018) and hence it is corrected as Brachystelma edule. 
Brachystelma glabrum Hook.f., Fl. Brit. India 4(10): 65.1883.

Lectotype (designated here): INDIA, Deccan, 05.1882, Beddome s.n. (K000820005, digital image!).

Notes: Hooker (1883) described B. glabrum based on the specimens collected by Beddome from Deccan Peninsula. Meve (2002) cited "Type: Deccan, Beddome s.n. $[\mathrm{K}]^{\prime \prime}$, however, there are two specimens (1) K000820004 (Beddome 3, dated 12.1870) and (2) K000820005 (Beddome s.n. dated $5.1882)$ at $\mathrm{K}$. These are two different gatherings. Therefore, what Meve (l.c.) cited does not amounts to first step lectotypification. We have designated K000820005 as lectotype which agrees well with the protologue.

Brachystelma laevigatum (Wight) Hook.f., Fl. Brit. India 4(10): 65. 1883.

Eriopetalum laevigatum Wight, Contr. Bot. India 35. 1834.

Lectotype (First step: designated by Jagtap \& Singh 1999: 185 (K000820017, K001129085); second step: designated here): In sylvis Cossalae, Gorakhpur, 27.03.1814, F. Hamilton Wall. Asclep. n. 23 (K000820017, digital image!; isolectoype, K001129085 digital image!).

Notes: Within protologue, Wight (1834) cited the locality as 'In sylvis Cossalae, Gorukpur'. Jagtap and Singh (1999) cited Type: '(Kew photo!)'. There are two specimens at K (K000820017, K001129085) collected by Hamilton, of which we have designated K000820017 as lectotype.

Brachystelma maculatum Hook.f., Fl. Brit. India 4(10): 65.1883.

Lectotype (designated here or perhaps holotype): INDIA, Canara or Mysore, s.d., J.S. Law s.n. (K000820013, digital image!).

Notes: Hooker (1883) described B. maculatum based on the specimen collected by Law from Canara (Mysore). Jagtap and Singh (1999: 186) cited type as "Canara or Mysore, Law" however this is not effective typification as they did not cite the herbarium where the type is housed (Art. 9.22 of ICN, Turland et al., 2018). Meve (l.c.) cited type as "Deccan? Law s.n. K!". This also was not effective typification according to art. 7.11 of ICN (Turland et al., l.c.) as Meve (l.c) did not use the term 'designated here' or its equivalent. Unless the protologue shows that the description was based on a single specimen, it is doubtful whether
Hooker's description was based on a single specimen housed at $\mathrm{K}$. In such a situation the specimen housed at K (K000820013) is designated here as a lectotype which perhaps can be holotype.

Brachystelma volubile Hook.f., Fl. Brit. India 4(10): 65.1883.

Lectotype (First step: designated by Jagtap \& Singh 1999: 190 (K000794643 and K000794644); second step: designated here): INDIA, Cuddapah hills, 2000 ft, 11.1881, Beddome s.n. (K000794644, digital image!).

Notes: Hooker (1883) described Brachystelma volubile based on the collections from Cuddapah hills by Beddome. Jagtap and Singh (1999) cited "Type: The Carnatic: On the Cuddapah, hills alt. $2000 \mathrm{ft}$., Beddome (K)" which amounts to first step lectotypification as there are two specimens (K000794643, K000794644) at K. Of these K000794644 is selected as lectotype.

\section{Acknowledgements}

Authors are grateful to the curators of Botanical Survey of India (CAL, MH) for help during herbarium consultation, $\mathrm{K}$, for digital images, Dr. K.N. Gandhi (Nomenclatural Registrar, Harvard University Herbarium, US) and to anonymous reviewers for the critical comments which improved the text at great extent. One of us (SK) is thankful to the University Grant Commission (F.42/2006 (BSR)/ BL/14-15/0489 dated 01.07.2015) for financial assistance.

\section{Literature Cited}

Britto S.J. \& P.V. Bruyns 2016. Three new species of Brachystelma from Tamil Nadu, India. Haseltonia 22: 48-54.

Collett, H. \& W.B. Hemsley 1890. On a collection of plants from Upper Burma and the Shan states. J. Linn. Soc., Bot. 28: 89. t. 14.

Gamble, J.S. 1922. Decades Kewenses. Plantarum novarum in herbario horti regi consevatarum. Bull. Misc. Inform., Kew 1922(3): 120.

Hooker, J.D. 1883. The Flora of British India. Vol. 4. L. Reeve \& Co., London. pp. 64-66.

Jagtap, A.P. \& N.P. Singh 1999. Asclepiadaceae and Periplocaceae. Fascicles of Flora India 24. Botanical Survey of India, Calcutta. pp. 178190. 
Kambale, S.S., Surveswaran, S. \& S.R. Yadav 2014. Two new species of Brachystelma Sims (Apocynaceae: Asclepiadoideae-Ceropegieae) from the Western Ghats of India. Kew Bull. 69: 1-10.

Meve, U. 2002. Brachystelma. In: Albers, F. \& U. Meve (Eds), Illustrated Handbook of Succulent Plants: Asclepiadaceae. Spinger-Verlag, Berlin, Heidelberg, New York. pp. 20-46.

Prasad, K., Chorghe, A., Surveswaran, S. \& P. Venu 2017. Brachystelma mahendragiriense (Apocynaceae), new species from Odisha, India. Rheedea 27(2): 135-140.

Prasad, K., Narayana S.A. \& U. Meve 2018. Brachystelma ananthapuramense (Apocynaceae: Asclepiadoideae), a new species from Andhra Pradesh, India. Kew Bull. 73: 16. https://doi. org/10.1007/s12225-018-9740-y

Sardesai, M.M., Kambale, S.S., Govekar, R.S. \& V.I. Kahalkar 2017. Two new species of Brachystelma (Ceropegieae: Apocynaceae) from Peninsular India. Rheedea 26 (2): 142-149.

The Plant List 2013. Version 1.1 Published on the Internet; http://www.theplantlist.org/ (accessed 20.03.2018).
Turland, N.J., Wiersema, J.H., Barrie, F.R., Greuter, W., Hawksworth, D.L., Herendeen, P.S., Knapp, S., Kusber, W.H., Li, D.Z., Marhold, K., May, T.W., McNeill, J., Monro, A.M., Prado, J., Price, M.J. \& G.F. Smith (Eds.) 2018. International Code of Nomenclature for algae, fungi, and plants (Shenzhen Code) adopted by the Nineteenth International Botanical Congress Shenzhen, China, July 2017. Regnum Veg. 159. Koeltz Botanical Books, Glashütten. DOI https://doi.org/10.12705/Code.2018

Wight, R. 1834. Contributions to the Botany of India. Parbury, Allen \& Co., London.

Received: 03.04.2018

Revised and Accepted: 03.06.2018 